UDK: $632: 368$

DOI: $\underline{\text { https://doi.org/10.24867/12GI28Aleksic }}$

\title{
ANALIZA OSIGURANJA U POLJOPRIVREDI U SRBIJI U PERIODU OD 2015-2020. GODINE
}

\section{AGRICULTURE INSURANCE ANALYSIS IN SERBIA FOR THE PERIOD 2015-2020}

\author{
Marko Aleksić, Fakultet tehničkih nauka, Novi Sad
}

\section{Oblast - INDUSTRIJSKO INŽENJERSTVO I INŽENJERSKI MENADŽMENT}

Kratak sadržaj - Rad se bavi agrarom $i$ osiguranjem poljoprivredne proizvodnje u Srbiji. Prikaz osiguranja kroz istoriju sa posebnim osvrtom na osiguranje $u$ poljoprivredi kao jednoj od najrizičnijih grana privrede. Pažnja je usmerena na rizike koji pogađaju agrarnu proizvodnju i upravljanje rizicima. Osiguranje, kao jedan od bitnih činilaca za upravljanje rizicima, njegova zastupljenost $u$ poljoprivrednoj proizvodnji Srbije kao $i$ u osiguravajućim društvima. Da li je ovaj način upravljanja rizicima rentabilan sa stanovišta osiguranika $i$ osiguravača $i$ mere koje treba preduzeti za masovnije korišćenje ove vrste zaštite od potencijalnih rizika..

Ključne reči: Poljoprivredna proizvodnja, osigurane površine, premija osiguranja, tehnički rezultat

Abstract - The focus of this paper is on agriculture and agricultural insurance in Serbia. Its review of insurance throughout history highlights agricultural insurance as one of the most risky branches of the economy. Main emphasis consists of the risks that affect agricultural production as well as the risk management. Furthermore, it questions insurance, as one of the most important factors in risk management, its representation in Serbian agricultural production, as well as in insurance companies. Is the risk management method profitable from the insured people's and insurers point of view? What are some necessary measures that should be taken for mass use of this type of protection against potential risks?

Keywords: Agricultural production, insured area, insurance premium, technical result

\section{UVOD}

Poljoprivredna proizvodnja je jedna od najrizičnijih grana privrede. Suočava se sa bezbroj rizika. Svaka godina u poljoprivredi je neizvesna, počev od uspešnosti prinosa do plasmana proizvoda. Svi učesnici u lancu, od dobavljača do krajnjeg potrošača, izloženi su ovim rizicima. Njihovi odnosi su usko povezani, čitav lanac zavisi od niza međusobno isprepletenih okolnosti, tako da i najbezazlenija sitnica može imati dalekosežne posledice. Poljoprivredna proizvodnja, bez obzira da li se radi o biljnoj proizvodnji ili gajenju životinja, izložena je mnogim opasnostima.

\section{NAPOMENA:}

Ovaj rad proistekao je iz master rada čiji mentor je bio dr Đorđe Ćosić, vanredni prof.
Vremenske nepogode koje su poslednjih godina učestale na ovim prostorima, bilo gràd, poplave, suša, mraz ili neka druga prirodna katastrofa, biljne i životinjske bolesti. Visoke cene repromaterijala, niske cene gotovog proizvoda, su opasnost koja je svakodnevno prisutna u poljoprivrednoj proizvodnji. Tržište je u današnjim uslovima dosta nestabilno i podložno svakodnevnim promenama, a proizvodni ciklus u poljoprivredi je neizbežno duži u odnosu na mnogobrojne privredne grane. Na početku proizvodnog ciklusa teško je predvideti mnoge faktore, pa tako i institucionalne. Većinu opasnosti je teško izbeći, neke se mogu predvideti i izbeći ili ublažiti, ali je svakako najvažniji program upravljanja rizicima. Jedna od važnih spona u upravljanju rizicima je i osiguranje.

\section{AGRAR U SRBIJI}

Istorijski posmatrano, poljoprivreda igra važnu ulogu u ekonomskom i društvenom razvoju, ali i identitetu Srbije. Od snažnih agrarnih korena, razvili smo se u kulturu sa manje od 17 odsto poljoprivrednika (sa punim radnim angažmanom) koji sada proizvode hranu za sve građane. ${ }^{1}$

Od 8.840.000 hektara na koliko se prostire Srbija, 5.178.704 hektara je poljoprivredno zemljište, od toga obradivo zauzima površinu od 3.475.894 hektara a ostatak je pod šumama, livadama i pašnjacima i nekorišćenom zemljištu.

Agrarni sektor je veoma specifičan za Srbiju, njegovo učešće u stvaranju BDP-a je oko $11 \%$ sa $20 \%$ zaposlenog stanovništva.

U Srbiji je najviše zastupljeno ratarstvo sa $44 \%$, stočarstvo sa $41 \%, 12 \%$ pripada voćarstvu i vinogradarstvu, a ostatak od $3 \%$ pripada drugim kulturama. ${ }^{2}$ Grafikon 1. prikazuje strukturu poljoprivrede u Srbiji.

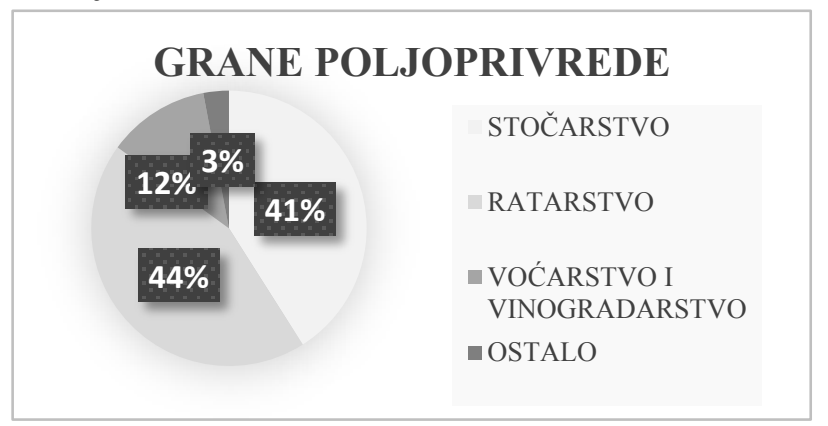

Grafikon 1. Grane poljoprivrede u Srbiji

\footnotetext{
${ }^{1} \mathrm{http}: / /$ voice.org.rs/poljoprivreda-u-srbiji-pala-na-nivonajsiromasnijih-zemalja-subsaharskog-regiona/

2 https://sr.wikipedia.org/sr
} 


\subsection{Osiguranje}

Osiguranje u savremenom svetu je izuzetno značajno, od nastanka do danas njegova uloga je da u potpunosti ili delimično sanira posledice štetnih događaja. Osiguranje je prenos rizika sa jednog entiteta na drugi.

Osiguranje nije tvorevina savremenog sveta, osiguranja su postojala i pre nove ere, pretpostavlja se 3000 p.n.e. Pisani tragovi o osiguranju postoje u Hamurabijevom zakonu iz 2250. p.n.e. u vidu uredbe o međusobnoj obavezi učesnika trgovačkog karavana da nadoknade štetu koja bi nastala u slučaju pljačke. ${ }^{3}$

Prvi vidljivi znaci osiguranja u Srbiji zabeleženi su u Dušanovom zakoniku iz XIV veka. Tu se pominje odgovornost za štetu. Miloš Obrenović je XIX veku uveo „opštinske koševe“, svaki seljak je morao da izdvoji određenu količinu žita, neka vrsta robne rezerve, koja se koristila kao pomoć narodu u slučaju suše, poplava i drugih nepogoda, koje bi uticale na rod. Formiranje „opštinskih koševa“ se smatra prvim pravim osiguranjem na prostoru Srbije. Domaća osiguravajuća društva nastala su u XX veku, do formiranja domaćih, ulogu osiguravača su obavljala strana osiguravajuća društva. Nakon propasti bečkog osiguravajućeg društva „Feniks“ i donošenjem Uredbe o nadzoru nad osiguravajućim društvima 1. marta 1937 godine smatra se i početkom osnivanja domaćih osiguravajućih društava.

\subsubsection{Osiguranje u poljoprivredi}

Osiguranje u poljoprivredi je poznato pod nazivima „Osiguranje useva i plodova“ i „,Osiguranje životinja“

\section{Osiguranje biljne proizvodnje}

Jedinstven naziv ovog vida osiguranja je ,osiguranje useva i plodova“, iako reč ,usev“ podrazumeva biljne kulture koje se svake godine zasejavaju, a reč ,plodovi“ označava višegodišnje zasade. Osiguranje biljne proizvodnje podrazumeva i sve druge biljne vrste koje nisu obuhvaćene ovim ustaljenim terminom osiguranja, bez obzira da li se radi o jednogodišnjim ili višegodišnjim usevima i zasadima. Predmet osiguranja mogu biti i biljne vrste iz oblasti hortikulture, šumske kulture do šeste godine starosti, kao i kulture koje nekontrolisano rastu, a koristi ih čovek za dalju proizvodnju (npr, trska). U zavisnosti koji deo biljne vrste je u upotrebi, odnosno koji se koristi za dalju proizvodnju ili potrošnju (plod, list, cvet, stablo...), taj deo je i predmet osiguranja.

\section{Osiguranje životinja}

Životinje koje se mogu osigurati su:

> Domaće životinje intenzivnog uzgoja - kopitari, goveda, ovce, koze, svinje, pčele, psi, pastrmke, fazani, nerčevi, ćurke, morke, paunovi i perad;

$>$ Divlje i egzotične životinje u zoološkim vrtovima i van njih.

Predmet osiguranja mogu biti samo zdrave životinje. Obolele, iscrpljene, zakržljale, životinje u lošoj kondiciji,

\footnotetext{
${ }^{3}$ https://studenti.rs/seminarski-radovi/istorijski-razvojosiguranje
}

kao i životinje koje se drže u lošim zoohigijnskim uslovima, ne mogu biti predmet osiguranja.

\subsubsection{Tipovi osiguranja}

$>$ Osnovni rizik;

$>$ Dopunski rizik;

$>$ Eksperimentalna osiguranja;

$>$ Osiguranje prinosa;

\subsubsection{Opasnosti - rizici}

Teško je reći da li je izloženost rizicima veća kod biljne ili životinjske proizvodnje. Biljna proizvodnja je izložena mnogobrojnim rizicima, lista je duga, dok stočarska proizvodnja poznaje samo dva rizika, bolest i uginuće.

Poljoprivredna proizvodnja je sve više izložena brojnim rizicima:

Tabela 7. Rizici i izvori rizika

\begin{tabular}{ll}
\hline \multicolumn{1}{c}{ Rizici } & \multicolumn{1}{c}{ Izvor rizika } \\
\hline Proizvodni rizici & Vremenski uslovi, pojava \\
štetočina \\
Tržišni rizici & Nestabilnost cena \\
Institucionalni rizici & Mere agrarne politike \\
Finansijski rizici & Cena izvora kapitala \\
Ljudski rizici & Nedostatak radne snage \\
\hline
\end{tabular}

\section{ANALIZA POLJOPRIVREDNOG OSIGURANJA U SRBIJI}

\subsection{Osigurane površine}

Koliko je razvijeno poljoprivredno osiguranje u Srbiji može se utvrditi analizom ukupno osiguranih površina, broja polisa kao i visine premija osiguranja i koji broj poljoprivrednih gazdinstava je podnelo zahtev za regresiranje osiguranja.

\section{Osigurane površine $u$ razdoblju 2015-2020}

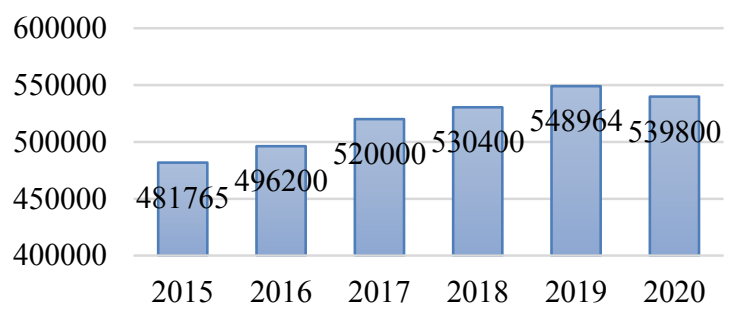

Grafikon 7. Osigurane površine u Srbiji od 20152020.godine (sopstveni proračun)

Grafikon 7. prikazuju ukupno osigurane površine po godinama u procentima za period od 2015-2020, godine. 2015. godine osigurano je $13,86 \%$ površina obradive zemlje, što je 9,30\% ukupnog poljoprivrednog zemljišta, 2016. godine $14,28 \%$ površina obradive zemlje, odnosno 9,58\% ukupnog poljoprivrednog zemljišta, 2017. godine 
procenat osiguranih obradivih površina je $14,96 \%$, a to je $10,04 \%$ ukupnog poljoprivrednog zemljišta, 2018. godine ukupno osigurane obradive površene iznose $15,26 \%$, što je 10,24\% ukupnog poljoprivrednog zemljišta, 2019. godine osigurano je $15,79 \%$ obradivih površina, odnosno $10,60 \%$ ukupnih poljoprivrednih površina, 2020. godine dostupan podatak je za prva dva kvartala i iznosi $15,53 \%$ površina obradive zemlje, a 10,42\% ukupne poljoprivredne površine.

\subsection{Premija osiguranja}

Premija osiguranja je novčani iznos koji ugovarač osiguranja treba da plati za osiguranje. Sastoji se od funkcionalne premije i režijskog dodatka, pri čemu se funkcionalna premija sastoji od tehničke premije, a može sadržati i doprinos za preventivu, ako je uračunat $u$ premiju osiguranja. Tehnička premija osiguravaču služi za podmirenje obaveza iz ugovora o osiguranju (za isplatu odšteta, ugovorenih suma osiguranja), kao i za izmirenje obaveza prema reosiguravaču za sve reosigurane rizike. Doprinos za preventivu služi za finansiranje aktivnosti namenjenih za prevenciju odnosno sprečavanje rizika. Režijski dodatak je deo premije koji je namenjen za obavljanje poslova osiguranja odnosno za troškove sprovođenja osiguranja. ${ }^{4}$

\section{5 Štete}

Šteta je ostvarenje osiguranog rizika. Kada nastupi šteta obe ugovorne strane dužne su da ispune svoj deo ugovorne obaveze. Osiguranik da prijavi štetu i preduzme sve mere za da bi sprečio ili ublažio posledice štetnog događaja. Osiguravač je dužan da u što kraćem roku izvrši uvid u štetu, izvrši procenu i nadoknadi osiguranu sumu u skladu sa ugovorom.

Tabela 7. Broj osiguranja, premija, broj šteta, tehnički rezultat

\begin{tabular}{llllll}
\hline & & & & & \\
$\begin{array}{l}\text { godi } \\
\text { na }\end{array}$ & $\begin{array}{l}\text { broj } \\
\text { osigura } \\
\text { nja }\end{array}$ & $\begin{array}{l}\text { premija } \\
\text { osiguranja } \\
\text { obraču } \\
\text { natih } \\
\text { šteta }\end{array}$ & iznos štete & $\begin{array}{l}\text { procenat } \\
\text { isplaćenih } \\
\text { šteta u } \\
\text { odnosu na } \\
\text { premije } \\
\text { osiguranja }\end{array}$ \\
\hline 2015 & 11.972 & 1.124 .236 & 7.608 & 1.025 .606 & $89,34 \%$ \\
2016 & 12.384 & 1.080 .053 & 14.031 & 2.067 .136 & $184,65 \%$ \\
2017 & 13.035 & 1.238 .126 & 13.295 & 2.380 .273 & $206,78 \%$ \\
2018 & 20.130 & 1.564 .760 & 19.130 & 3.136 .876 & $191,96 \%$ \\
2019 & 22.825 & 1.909 .174 & 19.827 & 3.261 .294 & $187,76 \%$ \\
2020 & 25.234 & 2.044 .639 & 0 & 0 & 0 \\
\hline
\end{tabular}

Najveći broj obračunatih šteta osiguranih useva i plodova je u 2018. godini, a najveći iznos isplaćenih šteta je zabeležen u 2019. godini. U 2019. godini najviše šteta se dogodilo u voćarskoj proizvodnji, koja ima daleko veću vrednost od ratarske proizvodnje. Majske poplave su nanale velike štete, gde je skoro 3000 ha pod zasadima voća potpuno uništeno. Najveća premija osiguranja je uplaćena 2019. godine i u odnosu na početnu posmatranu godinu (2015.g.) uvećana je 88,73\%, dok je obračunata šteta prema istim parametrima uvećana za 235,33\%. Stočarska proizvodnja takođe beleži najveći broj obračunatih šteta 2018. godine, a najveći iplaćen iznos po osnovu obračunatih šteta je u 2019. godini. Stočarska proizvodnja je takođe redukovana u majskim poplavama, bilo uginućem od vode ili uginućem od pojave bolesti izazvane nakon povlačenja vode, kao i nedostatkom hrane.

Iznos obračunatih šteta je zabeležio daleko veći rast od rasta premije osiguranja $\mathrm{u}$ analiziranom periodu, što potvrđuje činjenicu da se radi o osiguranju najrizičnije grane privrede.

\section{TEHNIČKI REZULTAT}

\subsection{Tehnička premija}

Tehnička premija osiguravaču služi za podmirenje obaveza iz ugovora o osiguranju (za isplatu odšteta, ugovorenih suma osiguranja), kao i za izmirenje obaveza prema reosiguravaču za sve reosigurane rizike.

\subsection{Tehnički rezultat}

Ono što je najvažnije u procesu osiguranja i za osiguravača i za osiguranika je tehnički rezultat. Praćenje i analiziranje tehničkog rezultata je jedan od najvažnijih segmenata u poslovanju osiguravajućih društava, i čini osnovni parametar u definisanju politike osiguranja. Tehnički rezultat je potrebno utvrditi ne samo za svaku granu poslovanja osiguravajućeg društva, već i u okviru svake grane po vrstama osiguranja, a u okviru vrste na podvrste. Tehnički rezultat prestavlja količnik šteta i tehničkih premija. Tehnički rezultat direktno utiče na poslovanje osiguravača. Učestali negativni tehnički rezultati bi doveli u pitanje opstanak društva. Ništa manje značajan tehnički rezultat nije za osiguranika koji bira adekvatno osiguravajuće pokriće.

2015. godina je godina oporavljanja od prekomernih poplava, koje su zadesile Srbiju 2014. godine. Ratarska proizvodnja, posebno pšenica je na zadovoljavajućem nivo, u odnosu na prošlu godinu smanjena je proizvodnja kukuruza, malina, rašećerne repe, suncokreta, soje, šljiva. Klimatski uslovi su uglavnom bili povoljni, tržište bez većih oscilacija. Proizvodnja u odnosu na 2014. godinu manja za 8\% (godišnji statistički podatak). 2015. godina je za analizirani period najbolja godina stočarske proizvodnje.

Povoljni klimatski uslovi koji su obeležili 2016. godinu, uticali su na kvalitetan i visok prinos pre svega ratarskih kultura. Smanjen rod je jedino zabeležen u voćarstu, višnje, maline, kajsije. Prinos u odnosu na 2015.godinu povećan je za 11 procenata.

2016. godina je karakteristična po smanjenom stočnom fondu, kao posledica destabilizacije domaćeg tržišta uzrokovana prekomernim uvozom, pre svega svinjskog mesa. Liberalizacija uvoza je direktno uticala na katastrofalni rezultat stočarske proizvodnje.

\footnotetext{
${ }^{4} \mathrm{ps}: / /$ centarzaosiguranje.com/recnik-osiguranja/
}

$\overline{{ }^{5} \text { https://www.sava-osiguranje.rs/sr-rs/recnik-osiguranja/ }}$ 
Smanjena proizvodnja i smanjen prinos u 2017. godini u odnosu na prethodnu godinu zabeležen je skoro u svim segmentima proizvodnje, od kukuruza, pšenice, soje, šećerne repe, suncokreta, malina, jabuka, kajsija, višanja, šljiva. Nepovoljni vremenski uslovi su dosta uticali na smanjen prinos, pre svega suša, koja je bila na nivou elementarne nepogode. Produžena zima u prolećnim mesecima je znatno pogodila termofilne kulture i bitno uticala na dalji razvoj, što je rezultiralo smanjenim rodom, lošijeg kvaliteta. Mraz, gràd i suša su obeležili 2017. godinu. Smanjena proizvodnja kukuruza je značajno uticala na proizvodnju stočne hrane, što je uzrokovalo klanje i prodaju stoke pre vremena.

Godina 2018. može se reći da je na nivou prosečne i po prinosima i po klimatu koji je obeležio ovu godinu. Nisu zabeležene klimatske katastrofe, prinos je uvećan u odnosu na prethodnu godinu, kod nekih kultura je zabeležen lošiji kvalitet zrna. Ono što obeležava ovu godinu su izuzetno niske cene. Zabeležen je blagi rast stočarske proizvodnje, što se skoro i nije osetilo u ovom segmentu proizvodnje. I dalje se oseća uticaj liberalizacije uvoza mesa, mleka, mlečnih i mesnih proizvoda. Ovu godinu je obeležio veliki pomor pčela.

2019. godina, teška godina za voćare, početkom vegetacije došlo je do izmrzavanja. Klimatske promene su se dosta odrazile i u ratarskoj proizvodnji. Značajna je za svinjarstvo zbog ukidanja obaveznog vakcinisanja protiv kuge. I ovu godinu obeležava pomor pčela.

Tehnički rezultat osiguranih useva i plodova u poslednjih šest godina je nepovoljan, samo 2015. godina beleži pozitivan tehnički rezultat. Visina utvrđene premije nije dovoljna za pokrivanje nastalih šteta. Tehnički rezultat osigurane stočarske proizvodnje je pozitivan samo u prvoj analiziranoj godini. Naredne četiri godine beleže negativan tehnički rezultat, odnosno obračunate štete premašuju iznos uplaćene premije osiguranja.

Ukoliko bi osiguravajuće društvo i dalje nastavilo sa negativnim rezultatom, a da nisu obezbeđene rezerve za pokriće, društvo bi poslovalo sa gubitkom. Određivanje visine premije osiguranja je izuzetno važno i ne može se adekvatno utvrditi bez stručne analize koja se bazira na analizi nastalih šteta iz ranijih godina.

\section{ZAKLJUČAK}

Procenat osiguranja poljoprivredne proizvodnje u Srbiji u odnosu na ukupno obradive površine i broj grla je izuzetno nizak. Biljna proizvodnja je osigurana u rasponu od $13-15 \%$, a stočarska se kreće od 3-5\%. Razlog ovako niskom procentu osiguranja treba tražiti, pre svega $u$ slaboj ekonomskoj moći. Individualni proizvođači, naročito oni koji poseduju manje površine, retko se odlučuju za ovaj vid zaštite od posledica opanosti zato što na osiguranje gledaju samo kao dodatni i nepotrebni izdatak, koji u velikoj meri opterećuje njihov skromni budžet.
Procenat učešća u osiguranju malih poljoprivrednih proizvođača je skoro zanemarljiv. Najvećim delom ovom vidu zaštite od mnogobrojnih rizika se odlučuju pravna lica i veliki individualni proizvođači. Štete koje mogu da ozbiljno ugroze njihovo poslovanje su daleko veće od izdvajanja sredstava za sprečavanje štetnih posledica, čak i da do njih ne dođe. Niskobudžetni poljoprivrednici se nadaju da do štete neće ni doći, a ako se ipak desi očekuju da neće biti katastrofalna.

Ako se posmatra tehnički rezultat, koji je izveden iz dostupnih podataka sa zvanične stranice NBS, čak se može i reći da je opravdan stav osiguravajućih društava za nedovoljan plasman ove vrste osiguranja, od pet analiziranih godina, samo jedna godina beleži dobar tehnički rezultat.

Aktivno učešće države kroz razne oblike je veoma važno, što se vidi iz primera razvijenih država. Mnogi rizici se ne mogu sprečiti, ali se mogu kontrolisati. Rizici su sastavni deo poslovanja u poljoprivredi i zato zahtevaju punu pažnju na svim nivoima.

\section{LITERATURA}

[1] Avdalović V., i dr. 2008. Upravljanje rizikom u osiguranju, Fakultet tehničkih nauka u Novom Sadu, Novi Sad.

[2] Drezgić Petar i dr. Procena šteta od gràda na usevima, Poljoprivredni fakultet u Novom Sadu, Institut za ratarstvo i povrtarstvo,1977.g.

[3] Iturrioz Ramiro, 2009. Agricultural Insurance, Example Series on Insurance, Washington,USA

[4] Todor Marković, 2009. Osiguranje useva i plodova kao instrument za upravljanje rizikom $\mathrm{u}$ poljoprivredi, Letopis naučnih radova, godina 33 , broj I, strana 28-35.

[5] http://voice.org.rs/poljoprivreda-u-srbiji-pala-nanivo-

najsiromasnijih-zemalja-subsaharskog-regiona/

[6] https://sr.wikipedia.org/sr

[7] https://studenti.rs/seminarski-radovi/istorijski-

razvoj-osiguranje

[8] ps://centarzaosiguranje.com/recnik-osiguranja/

[9] https://www.sava-osiguranje.rs/sr-rs/recnikosiguranja/

\section{Kratka biografija:}

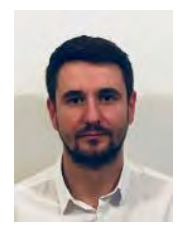

Marko Aleksić rođen je u Novom Sadu 1986. god. Srednju elektrotehničku školu završio u Novom Sadu, Poslovni i pravni fakultet u Beogradu, Master rad na Fakultetu tehničkih nauka iz oblasti Industrijsko inženjerstvo i inženjerski menadžment odbranio na temu Analiza osiguranja u poljoprivredi u Srbiji u periodu 2015-2020. g odbranio je 2020.god. kontakt: aleksic.marko26@gmail.com 